\title{
Nasal polyposis
}

\author{
Gerald A. BROWN* \\ M.B., Ch.B., F.R.C.S. \\ Senior Registrar, \\ Ear, Nose and Throat Hospital, Glasgow
}

\section{Summary}

A review of 313 cases of nasal polyposis indicates that there is a high incidence of recurrence in this disease. Other nasal pathology affects a significant number of these patients. Simple surgical removal of the polypi by a transnasal route is the common mode of treatment.

\section{Introduction}

Most allergists and rhinologists will have realized that their treatment for patients with nasal polyposis is far from satisfactory. The chronicity of this disease is evident from the number of recurrences which one sees in the Out-Patient Department each week.

I have undertaken a review of all the cases who have presented at the Ear, Nose and Throat Hospital, Glasgow, with nasal polyposis during the period August 1965 to August 1968. Some of these patients attended with recurrent polyposis and many had other ear, nose or throat disease.

Treatment for patients with nasal polyposis is essentially symptomatic and recurrences are common despite the huge array of both medical and surgical treatments which are used today, 1965 (Walsh, 1950; Weille, 1955, 1965; Weille \& Gohd, 1956; Hollander,1962; Blumstein, 1966; Greenburg, 1966).

\section{Results}

During the period August 1965 to August 1968, 313 patients attended the Ear, Nose and Throat Hospital, Glasgow, with the diagnosis of nasal polyposis.

Two hundred and fourteen patients were male; ninety-nine were female. The ages of these patients ranged from 6 to 84 years (see Fig. 1).

\footnotetext{
* Present address: Senior Registrar, Ear, Nose and Throat
} Infirmary, Liverpool.

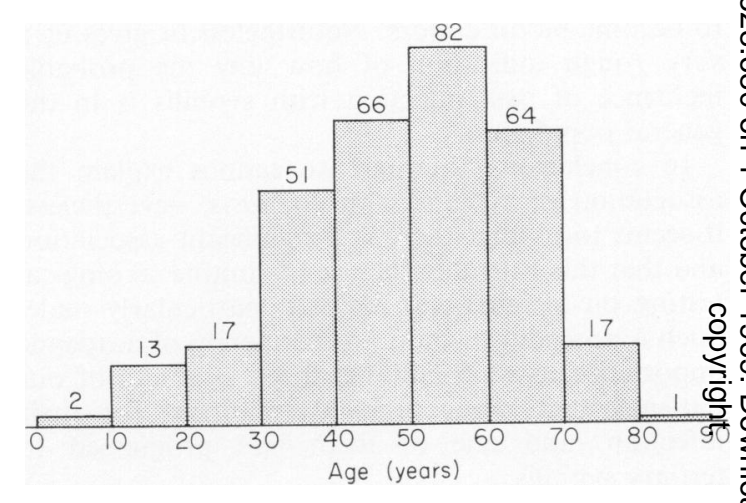

FIG. 1. Age incidence of patients with nasal polyposis.

All patients presenting for the first time were $\overrightarrow{\overrightarrow{0}}$ placed on the waiting list to have the polypi removed 3 by a transnasal approach, usually using a topical nasal anaesthetic.

One surgical removal of the polypi was performed $\bar{t}$ on $167(53 \%)$ patients. Polypi were removed twice on eighty $(26 \%)$, three times on thirty-eight $(12 \%)$ and more than three times on twenty-eight $(9 \%)$ of the patients.

Of those specimens which were examined histologically it was not always possible to state whether 의 they were of an allergic or infective origin and many showed evidence of both features.

Sixty-two patients had recurrence of their disease o within 1 month of operation.

The time-interval between recurrences ranged $N$ from less than 1 month to 27 years, the average $N$ being $2 \frac{1}{2}$ years.

Patients who had no recurrence of their nasalo polyposis 1 month after operation were generally $\mathbb{\complement}$ dismissed to be seen again as requested.

Bilateral nasal polyposis was found in 222 patients, 0 unilateral disease in ninety-one. 
TABLE 1. Nasal operations performed on patients with nasal polyposis

\begin{tabular}{cccccc}
\hline $\begin{array}{c}\text { Antral } \\
\text { washouts }\end{array}$ & SMR & $\begin{array}{c}\text { Cautery or } \\
\text { trimming of } \\
\text { turbinates }\end{array}$ & $\begin{array}{c}\text { Intranasal } \\
\text { antrostomy }\end{array}$ & $\begin{array}{c}\text { Radical } \\
\text { antrostomy }\end{array}$ & $\begin{array}{c}\text { Others: } \\
\text { rhinoplasty; } \\
\text { lateral rhinotomy }\end{array}$ \\
\hline 26 & 45 & 15 & 5 & 10 & 2 \\
\hline
\end{tabular}

TABLE 2. Other operations performed on patients with nasal polyposis

\begin{tabular}{ccccc}
\hline Tonsillectomy & Stapedectomy & Mastoidectomy & Laryngoscopy & $\begin{array}{c}\text { Suction clearance } \\
\text { of middle ear }\end{array}$ \\
\hline 3 & 2 & 2 & 2 & 2 \\
\hline
\end{tabular}

The average duration of symptoms admitted by the patient before attending the Out-Patient Department was 13 months.

The various operations carried out on these patients can be seen in Tables 1 and 2 .

Neoplasms in the nose and nasopharynx may be removed as nasal polypi and the true diagnosis only realized when the specimens are examined histologically.

Several cases of squamous metaplasia, one case of carcinoma in situ and one case of invasive squamous carcinoma were reported histologically. In one instance a case of nasopharyngeal fibroma was described and in another, a case of plasmoblastoma.

A case of capillary haemangioma and three cases of osteoma of the nasal cavity were removed at operation and proven histologically.

\section{Discussion}

This review of cases shows that nasal polyposis affects a wide age-group, males being more than twice affected than females.

Despite the fact that many authorities believe that allergy is responsible for nasal polyposis (Kern \& Schenck, 1934; Stewart \& Kawa, 1953, 1954; Hargrove, 1954; Silberg \& Catchpole, 1956; Hajos, 1959; Schenck, 1959; Weisskopf \& Burns, 1959; Hlavacek, 1962; Stewart, 1963; Sanders, 1964; Blumstein, 1966), there were ninety-one cases of unilateral disease which would tend to lend weight to an aetiology of localized disease such as local vasomotor imbalance, as suggested by GoldingWood $(1961,1962)$ and Walsh (1950).

Medical treatment is widely used and advocated for this disease. The systemic or local uses of decongestants of an antihistaminic or adrenergic type were widely used in these patients (see Table 3 ).

The systemic use of steroids as suggested by Stewart \& Kawa (1953, 1954), Dolowitz \& Dougherty (1961) and Stewart (1963), and the local use of steroids as described by Stewart \& Kawa (1954) and Myers (1958) have proved more useful in some cases.

I have treated a small number of patients suffering from recurrent nasal polyposis with systemic steroids in the form of prednisolone tablets. The dosage is started at a level of $5 \mathrm{mg}$ t.i.d. for 7 days then $5 \mathrm{mg}$ b.d. until the regression of symptoms stabilizes, usually about 2 more weeks. A progressively falling dosage is given until the lowest maintenance dosage compatible with keeping the patient symptom-free is reached, usually about $2-2.5 \mathrm{mg}$ day. These patients have now been on treatment for periods raniging up to 2 years and all continue to be controlled. One marked benefit has been the return of the sense of smell. The long-term effects of steroid drugs on the bones, however, must always be borne in mind. An attempt to desensitize the patients against specific allergens is indicated by Kern \& Schenck (1934) and Hajos (1959), and is still widely used. Treatments using thyroid extract as suggested by Walsh (1950) or splenic extract as suggested by Stoll (1963), and the use of radiation therapy suggested by Hollander (1962) and Tarasov (1964) have never become generally accepted.

Surgery. No patient in this series managed to avoid surgical operation due to the action of medical treatment apart from steroids, when nasal polypi were present and producing symptoms.

However, the results show that the surgical treatment used in this series was often ineffective, only $53 \%$ of patients being 'cured' by one surgical removal of polypi; this is a lower figure than that suggested by Blumstein (1966).

Surgical removal of their polypi required the patients to stay in hospital for an average of 4-5 days. A simple transnasal removal with forceps or snare using topical nasal anaesthesia has been the usual treatrnent, as advocated by Wilson (1960) and Blumstein (1966).

The results show that this method is inadequate treatment for recurrent polyposis. Several reasons could be put forward to explain this fact, but since 
TABLE 3. Decongestant therapy

\begin{tabular}{|c|c|}
\hline Nasal drops or sprays & Systemic therapy \\
\hline $\begin{array}{l}\text { 1. Antazoline sulphate } \\
\text { Naphazoline nitrate } \\
\text { (Antistine-privine) }\end{array}$ & $\begin{array}{l}\text { 1. Triprolidine hydrochloride } \\
\text { Pseudoephedrine hydrochloride } \\
\text { (Actifed) }\end{array}$ \\
\hline \multirow{2}{*}{$\begin{array}{l}\text { 2. Ephedrine hydrochloride } \\
\text { 3. Tramazoline hydrochloride } \\
\text { Dexamethazone } \\
\text { Neomycin } \\
\text { (Dexarhinaspray) }\end{array}$} & $\begin{array}{l}\text { 2. Diphenhydramine hydrochloride } \\
\text { (Benadryl) }\end{array}$ \\
\hline & $\begin{array}{l}\text { 3. Pheniramine } p \text {-amino- } \\
\text { salicylate } \\
\text { (Daneral) }\end{array}$ \\
\hline $\begin{array}{l}\text { 4. Phenylephrine hydrochloride } \\
\text { (Fenox) }\end{array}$ & \multirow{2}{*}{$\begin{array}{l}\text { 4. Ephedrine sulphate } \\
\text { Diphenylpyrodine hydrochloride } \\
\text { Trifluoperazine } \\
\text { (Expansyl) }\end{array}$} \\
\hline $\begin{array}{l}\text { 5. Xylometazoline hydrochloride } \\
\text { Antazoline sulphate }\end{array}$ & \\
\hline (Otrivine-antistin) & \multirow{2}{*}{$\begin{array}{l}\text { 5. Cyproheptadine hydrochloride } \\
\text { (Periactin) }\end{array}$} \\
\hline 6. Naphazoline nitrate & \\
\hline (Privine) & \multirow{2}{*}{$\begin{array}{l}\text { 6. Promethazine hydrochloride } \\
\text { (Phenergan) }\end{array}$} \\
\hline 7. 2-Aminoheptane sulphate & \\
\hline (Tuamine) & $\begin{array}{l}\text { 7. Chlorpheniramine maleate } \\
\text { (Piriton) }\end{array}$ \\
\hline \multirow{3}{*}{$\begin{array}{l}\text { 8. Methoxamine hydrochloride } \\
\text { (Vasylox) }\end{array}$} & $\begin{array}{l}\text { 8. Triprolidine hydrochloride } \\
\text { (Proactidil) }\end{array}$ \\
\hline & $\begin{array}{l}\text { 9. Phenindamine tartrate } \\
\text { (Theophorin) }\end{array}$ \\
\hline & $\begin{array}{l}\text { 10. Phenylpropanolamine hydrochloride } \\
\text { Mepyramine maleate } \\
\text { Pheniramine maleate } \\
\text { (Triominic) }\end{array}$ \\
\hline
\end{tabular}

sixty-two $(19 \%)$ patients showed recurrence of their disease within 1 month of operation, I think it is not unlikely that this is because polypoidal mucosa could not be completely removed by the transnasal approach. Since no immediate medical treatment was administered post-operatively to try to control the pathological changes in the mucosa, the situation was ideal for a rapid recurrence of polyposis.

Many cases of recurrent polyposis involve the ethmoid sinus complex which is difficult to clear completely by a transnasal approach. Some form of ethmoidectomy, either by an external or transantral approach, would, with the help of the operating microscope, enable a more complete removal of disease to be performed.

Post-operative medical treatment in chronic cases, using steroids, would enable the nasal mucosa to recover by inhibiting the common pathological finding in nasal polypi, namely the accumulation of connective tissue ground substance (Weisskopf \& Burns, 1959; Dolowitz \& Dougherty, 1961).

Oral steroids, rather than ACTH as suggested by Stewart \& Kawa (1953, 1954), would be more acceptable and would enable the patients to be followed up at intervals in the Out-Patient Department.

Electrocautery or trimming of the turbinates has not featured as a treatment for patients in this series, but is used at the Ear, Nose and Throat Hospita Glasgow, where turbinate hypertrophy is present alone. Zinc ionization has not been used in this series of patients.

It is an interesting fact that eighty-two cases of septal deflection were found and this supports the claim of Gray (1967) that such a deformity is aetiological in the pathogenesis of nasal polyposis.

\section{Conclusions}

(1) Recurrence of nasal polyposis is common, occurring in $47 \%$ of patients.

(2) Simple transnasal polypectomy is inadequate treatment for recurrent polyposis.

(3) All specimens removed at operation should be examined histologically.

\section{Acknowledgments}

I would like to thank the Surgeons of the Ear, Nose and $\mathcal{N}$ Throat Hospital, Glasgow, who allowed me to review their cases, and for their helpful comments.

I am also indebted to the office staff for their help in extracting the case records.

\section{References}

Blumstein, G.I. (1966) Nasal polyps. Arch. Otol. 83, 266. Dolowitz, D.A. \& DougherTy, T.F. (1961) Nasal polyposis. Arch. Otol. 74, 171. 
Golding-Wood, P.H. (1961) Observations on petrosal and vidian neurectomy in chronic vasomotor rhinitis. $J$. Laryng. 75, 232.

Golding-Wood, P.H. (1962) Pathology and surgery of chronic vasomotor rhinitis. J. Laryng. 76, 969.

GrAY, L. (1967) Deviated nasal septum. III. Its influence on the physiology and disease of the nose and throat. $J$. Laryng. 81, 953.

GreENBERG, J. (1966) Nasal surgery in the treatment of allergy. Mod. Treatment, 3, 891 .

HaJos, K. (1959) Uber eine Desensibilisierungsmethode bei Rhinitis Allergica und Polyposus nasi. Der Schnupfen (Ed. by D. Eigler and D. G. R. Fundeisen), p. 78. Johann Ambrosius Barth, Leipzig.

Hargrove, S.W.G. (1954) Nasal polyposis. Proc. roy. Soc. Med. 47, 1015.

HlavaceK, V. (1962) Bacterial allergy as a cause of nasal polyps. Allergy Asthma, 8, 195.

Hollander, A.R. (1962) Nasal polyps. Review of current concepts and procedures for prevention of recurrences. Eye, Ear, Nose Thr. Monthly, 41, 922.

KERN, R.A. \& SCHENCK, H.P. (1934) Importance of allergy in aetiology and treatment of nasal mucous polyps. $J$. Amer. med. Ass. 103, 1293.

MYERS, D. (1958) The treatment of the allergic nasal polyp by the intrapolyp injection of prednisolone T.B.A. Laryngoscope, 68, 1.

SANDERS, S.H. (1964) Nasal polyps. Eye, Ear, Nose Thr. Monthly, 43, 76 also 72 (March), 71 (April) and 90 (September).

SCHENCK, H.P. (1959) Discussion of histochemical studies of pathology of nasal polyps by Weisskopf, A. and Burn, H.F. (same Journal). Trans. Amer. laryng. Ass. 80, 236.
Silberg, S. \& CATChPole, H.R. (1956) Orosmomucoid and protein content of nasal polyps. Fed. Proc. 15, 171.

Stewart, J.P. (1963) Allergy and nasal polyposis. Proc. roy. Soc. Med. 56, 221.

Stewart, J.P. \& KAWA, M.Z. (1953) Observations on the effect of cortisone and ACTH on the treatment of allergic rhinitis. Proc. roy. Soc. Med. 46, 131.

StewarT, J.P. \& KaWA, M.Z. (1954) Further observations on the effect of cortisone and ACTH on the treatment of allergic rhinitis. J. Laryng. 68, 193.

Stoll, H.G. (1963) Spenic extracts treatment in vasomotor, allergic rhinitis and nasal polyposis. H.N.O. (Berl.), 11, 151.

TARASOV, D.I. (1964) Use of X-ray therapy in prevention of recurrences of nasal polyps in pre- and post-operative periods. Oto-rino-laring. (Buc.), 9, 311 .

WALSH, T.E. (1950) Vasomotor rhinitis. Laryngoscope, 60, 360.

WeILle, F.L. (1955) The treatment of chronic vasomotor rhinitis. Med. Clin. N. Amer. 39, 1439.

WeILle, F.L. (1965) Rhinological methods for controlling nasal polyposis and vasomotor rhinitis. Trans. Amer. laryng. Ass. 86, 122.

WeIlle, F.L. \& GoHD, R.S. (1956) Virus theory of nasal polypaetiology and its practical applications. Ann. Otol. 6, 433.

Weisskopf, A. \& Burns, H.F. (1959) Histochemical studies of the pathogenesis of nasal polyps. Trans. Amer. laryng. Soc. 80, 236.

Wilson, C.P. (1960) Nasal polyps. J. Laryng. 74, 90. 